\title{
The making of Transparent Soap From Green Tea Extract
}

\author{
Tuty Anggraini, Sahadi Didi Ismanto and Dahlia \\ Faculty of Agricultural Technology, Andalas University, 25163 West Sumatra, Indonesia \\ E-mail: tuty_anggraini@yahoo.co.id
}

\begin{abstract}
This study aims to determined the effect of green tea extract on the characteristics of transparent soap and antioxidant activity as well as to determine the best concentration of the addition of green tea extract. This study used a completely randomized design (CRD) consisting of 5 treatments and 3 repetitions. Data were analyzed statistically using ANOVA followed by Duncan's test New Multiple Range Test (DNMRT) at 5\%. Treatment in this research were the addition of green tea extract $0 \% ; 0.5 \% ; 1 \% ; 1.5 \%$; and $2 \%$. The analysis on the transparent soap product were sensory evaluation test, irritation test, antimicrobial test, antioxidant activity, and chemical properties that include water content, $\mathrm{pH}$, the amount of fatty acid, the saponified fraction, alkali-free / free fatty acids, and insoluble part in alcohol . The results showed that the difference in the concentration of green tea extract in a transparent soap significantly affect insoluble part in alcohol, antioxidant activity, and antimicrobial, but did not significantly affect to moisture content, the level of fatty acid, unsaponified fraction, free fatty acids, pH, hardness, and degree of foam. Effect of green tea extracts in the manufacture of transparent soap in treatment $\mathbf{E}$ (Addition of green tea extract $2 \%$ ) is the best product, the value for color was $25 \%$, aroma was $50 \%, 20 \%$ transparency, hardness $35 \%$, and degree of foam was 70 while the hardness was $2,90 \mathrm{~N} /$ $\mathrm{cm} 2$; degree of foam $\mathbf{4 8 . 9 5 \%}$; the water content of $35.35 \% ; 29.78 \%$ the amount of fatty acids; unsaponified fraction was $12.87 \%$; free fatty acids $0,23 \%$; $\mathrm{pH}$ was 9.78 ; Insoluble parts in alcohol $2.08 \%$; irritation value 0 ; antioxidant activity of $15.21 \%$ and a diameter anti-microbial of $42 \mathrm{~mm}$. A transparent soap with the addition of green tea extract deserves to be developed.
\end{abstract}

Keywords-green tea extract, transparent soap, green tea

\section{INTRODUCTION}

Soap is a daily product which have a lot of purposes. More diversity of personal needs and customer prefferences, soap products are now very varied, such as opaque soap, liquid soap and transparent soap. Opaque soap is kind of regular soap which is solid and not transparent, liquid soap is soap formed in liquid, while the transparent soap is kind of soap which usually use for face and for showers that can produce a softer foam to the skin and lustrous appearance when compared with other soap. Transparent soap is relatively more expensive compared to other soaps which also usually consumed by the upper middle class [1].

Soaps which have good quality, are affected by the raw material used. The main raw material for making soap is fat or oils obtained from plant and animal. Oil used in this research was coconut oil. Coconut oil is easily saponified. The most predominant fatty acid in coconut oil is lauric acid. Lauric acid is indispensable for making soap caused by saturated fatty acid contained on lauric acid which is capable of providing excellent foaming properties for soap products Lauric acid as a raw material will produce soaps with high solubility and good foam characteristics [2].

Soap is composed of fatty acids, oils and waxes, which the compound containing unsaturated bonds which are easy to be oxidized and easy to generate bad aroma. To maintain the quality of the soap from the oxidation reaction need antioxidant agents to prevent it. Antioxidant is compounds that can inhibit or prevent oxidation on the substrate which is easily oxidized and has been widely used by the community. Based on the source of antioxidant grouped into two naturally derived antioxidant (natural antioxidant) and synthetic (synthetic antioxidant). In this research, antioxidant was used, derived from natural antioxidants contained in green tea.

Several previous researchs have shown that green tea is useful as an antibacterial, antioxidant, anti-inflammatory and anticancer [3]. The active substance in green tea are catechins, epicatechin (EC), galokatekin (GC), epigallocatechin (EGC), epigallocatechin gallate (EGCG), epicatechin gallate (ECG). The compounds are grouped in polyphenolic compounds [4].

Green tea is beneficial for beauty. The content of vitamin $\mathrm{E}$ and $\mathrm{C}$ in green tea can counteract free radicals caused premature aging also reduce the risk of cancer. Green tea contains catechins which has function as an antioxidant [5].

Pre-research has been done to find a transparent soap formulations when were added green tea. The additions of green tea extract were starting from a concentration of $0.5 \%$ $5 \%$. From the results of pre research, exceeding 
concentrations of green tea extract $2 \%$ may impair the transparency of the transparent soap, so in this research used concentration of green tea extract as followed $0.5 \% ; 1 \%$; $1.5 \%$ and $2 \%$ of the weight of the soap.

\section{MATERIALS AND METHOD}

The raw material for transparent soap were coconut oil, green tea extract, sugar, distilled water, ethanol, glyserin, $\mathrm{NaOH}$, straric acid, $\mathrm{NaCl}$, citric acid. The chemicals used in this research were $\mathrm{KOH}, \mathrm{HCl}$, diphenyl pycryl hydrazyl, NA medium.

\section{A. Research Design}

Research design was used to analyze the research data that was completely randomized design (CRD) with 5 treatment and 3 repetitions. So that overall there were 15 units of this research trial. The treatments were to find out concentration of the addition of green tea extracts for making transparent soap from coconut oil. The concentration of the addition of green tea extract that is based on the research pre $0.5-2 \%$ with the details as followed:

Treatment $\mathrm{A}=$ Without green tea extract

TreatmentB $=$ Green tea extract $0,5 \%$

Treatment $\mathrm{C}=$ Green tea extract $1 \%$

Treatment $\mathrm{D}=$ Green tea extract $1,5 \%$

Treatment $\mathrm{E}=$ Green tea extract $2 \%$

This following below were formulation of transparent soap processing.

TABLE I

FORMULATION OF TRANSPARENT SOAP PROCESSING

\begin{tabular}{|l|c|c|c|c|}
\hline \multirow{2}{*}{ Material } & \multicolumn{4}{c|}{ Treatment } \\
\cline { 2 - 5 } & A & B & C & D \\
\hline Coconut Oil (g) & 30 & 30 & 30 & 30 \\
\hline Stearic Acid (g) & 5 & 5 & 5 & 5 \\
\hline Citric Acid (g) & 0,3 & 0,3 & 0,3 & 0,3 \\
\hline Sodium Chloride (g) & 0,2 & 0,2 & 0,2 & 0,2 \\
\hline Sodium Hydroxide (g) & 5 & 5 & 5 & 5 \\
\hline Ethanol (g) & 19 & 19 & 19 & 19 \\
\hline Sugar Syrup (g) & 5 & 5 & 5 & 5 \\
\hline Glycerin (g) & 5 & 5 & 5 & 5 \\
\hline Aquades (ml) & 20 & 20 & 20 & 20 \\
\hline Green Tea Extract (\%) & 0 & 0,5 & 1 & 1,5 \\
\hline
\end{tabular}

\section{B. Green Tea Extraction [6]}

50 grams Dried green tea leaf powder was macerated using $150 \mathrm{ml}$ of $96 \%$ ethanol for 60 minutes at ambient temperature. After that, baking soda was added $0.7 \%$ of the amount of solvent. Then, filtered the solution which after that the liquid extract was evaporated by using a vacuum evaporator. Optimum conditions obtained when the evaporation on the flask $90 \mathrm{mBar}$ pressure and bath temperature $40^{\circ} \mathrm{C}$.

\section{Transparent Soap From Coconut Oil By addition of Green Tea Extract Processing [7]}

- 5 grams of stearic acid was melted at a temperature of $70-80^{\circ} \mathrm{C}$.

- 30 grams of coconut oil was heated and also stirred with by using magnetic stirrer which $550 \mathrm{rpm}$ at temperature $\pm 70^{\circ} \mathrm{C}-80^{\circ} \mathrm{C}$ for 5 minutes.
- Added stearic acid that has been melted, 0.3 grams of citric acid, and 0.2 grams of $\mathrm{NaCl}$. Then, stirred until homogeneous \pm 5 minutes. The temperature was maintained $70-80^{\circ} \mathrm{C}$.

- Add 5 grams of $\mathrm{NaOH}$. $\mathrm{NaOH}$ was dissolved in $15 \mathrm{ml}$ of distilled water, then stirred until trance. Trance is a condition where the soap has been formed signed as the end of the mixing process which also the soap mixture begins to thicken. When it was touched with a spoon, then scoop in few seconds still lasting scars. The difference between the temperature of $\mathrm{NaOH}$ solution with a mixture of oil and stearic acid should not be more than $50^{\circ} \mathrm{C}$.

- Then, 19 grams of ethanol was added and stirred until homogeneous \pm 5 minutes. After that, added molasses ( 5 grams of sugar has been dissolved in $5 \mathrm{ml}$ of distilled water), then added glycerin 5-6 grams. Stirred until all the soap is dissolved.

- The temperature was lowered to $40^{\circ} \mathrm{C}$, added green tea extract according to treatment $(0.5 ; 1.0 ; 1.5 ; 2.0 \%)$

- The mixture is poured into a mold, after \pm 10 minutes covered with plastic then storage at ambient temperature for 24 hours until the soap hardens.

- Further analysis of the soap (organoleptic, chemical properties, irritation test, antioxidant and antimicrobial activity).

\section{Observations}

The observations were consist of the observation of green tea extract and observations transparent soap added green tea extract. Observation of green tea extract was consist of an antioxidant activity, while the observation of transparent soap were consist of an sensory evaluation test, chemical properties of soap, irritation test, antimicrobial test, antioxidant activity and determining basic cost of transparent soap. Sensory evaluation test determined prefferences of panellist to color, aroma, transparency of soap, hardness, and foam stability. Observation of hardness and foam stability also were determined using objective method . Chemical properties observation were consist of water content, fatty acid value, unsanponiable matter, insoluble parts in alcohol, alkali-free / free fatty acid, and $\mathrm{pH}$. Chemical properties were determined according to SNI 06-3532-1994.

\section{E. Analysis Method}

All treatments will be determined such as its sensory evaluation (color, aroma, transparency soap produced, violence, and a lot of foam or foam stability), chemical properties (moisture, fatty acid value, unsanponiable matter, insoluble parts in alcohol, alkali-free, and $\mathrm{pH}$ ), irritation test, antioxidant activity and antimicrobial test. Results from observational data of test chemical properties except alkalifree, irritation test, and antimicrobial test were statistically tested by $\mathrm{F}$ test at $5 \%$ level and were continued with DNMRT test (Duncan's New Multiple Range Test) if significantly different.

\section{F. Sensory Envaluation Test [8].}

Sensory evaluation test in a transparent soap was aimed to determine the level of consumer preferences for color, aroma, soap transparency, hardness, and foam stability. This 
test used untrained panelists which consist of 20 people with a scale of preferences in numerical 1-5. Scale explanations were (1) very not like (2) not like, (3) average, (4) like, (5) very like. Observation of hardness and foam stability also were determined using objective method.

\section{G. Color, Aroma, and Transparency}

Assessment of panellist preferences to colors, aroma, and transparency of transparent soap was done visually. This test used untrained panelists of 25 people with a scale of preferences in numerical 1-5. Scale explanations were (1) very not like (2) not like, (3) average, (4) like, (5) very like.

\section{H. Hardness}

Soap hardness has been done visually and using a penetrometer. Sensory evaluation test was conducted as visual test on soap which determined panelist preferences on soap hardness. This assessed the soap hardness by seeing and feeling, then converted to numerical scale of their preferences.

For hardness test using penetrometer, samples were placed under penetrometer needle with the right conditions which the needle tip of penetrometer should be touched the surface of the sample. Control button was pressed and allowed to penetrate the material for \pm 5 seconds. Measurements were taken at three different points. The end result was the average of the three points (9).

$$
\text { Hardness }(\mathrm{mm} / \mathrm{sec})=\frac{01 \text { mms dspr of medls }}{\text { long ht of time to penetrate }}
$$

\section{Foam Stability}

Foam stability has been done using two different method which visually and using tools. Visual test has been done by sensory evaluation test which was assessing preferences. Panelist assessed by washing the hands with soap, then panelists assessed foam stability acording to their perceived.

Another method has been done by weighing $\pm 1 \mathrm{~g}$ a sample, added $10 \mathrm{ml}$ of water and then inserted into a beaker, stirred with a magnetic stirrer for 15 minutes. Water foam was poured into a measuring cup, measure the initial foam height and foam height after settling 15 minutes [10].

$$
\text { Foam Stability }(\%)=\frac{\text { antsr haight of foam }}{\text { Esguning haight of foom }} \times 100 \%
$$

\section{J. Chemical Properties}

Chemical properties of transparent soap has been determined by conducting some analysis such as water content, fatty acid levels, unsanponiable matter, insoluble parts in alcohol, alkali-free, and $\mathrm{pH}$.

\section{K. Water Content [11]}

$\pm 4 \mathrm{~g}$ of sample which has been prepared which has been known cup its weight. Preheat to oven at $105^{\circ} \mathrm{C}$ for 2 hours until the weight remains.

$$
\text { Water Content }=\frac{w_{1}-w_{2}}{w} \times 100 \%
$$

\footnotetext{
$\mathrm{W}_{1}=$ samples weight + cup $($ gram $)$

$\mathrm{W}_{2}=$ dried samples weight (gram)

$\mathrm{W}=$ sample weight (gram)
}

\section{Fatty Acids Levels [11]}

Approximately 2 grams of sample was put into a beaker, added $25 \mathrm{ml}$ of hot water, heated over a water bath until the sample dissolves completely, then put in a flask scale Cassia at least $0.1 \mathrm{ml}$. The rest of the sample in a glass cup rinsed with distilled water and the water poured into the flask. Then added a few drops of orange metal indicators and 10-15 ml of $\mathrm{HCl} 10 \%$ (or $7-10 \mathrm{ml}$ of $\mathrm{H} 2 \mathrm{SO} 425 \%$ ). Float of free fatty acids and the solution changes color to pink.

Cassia flask containing the sample solution was heated in a water bath with a neck condition flask half submerged in water. After the fatty acids was a separated and floated, added hot water until fatty acids was between scale division on the neck of the flask. The solution was heated continuously for approximately half an hour at $100^{\circ} \mathrm{C}$.

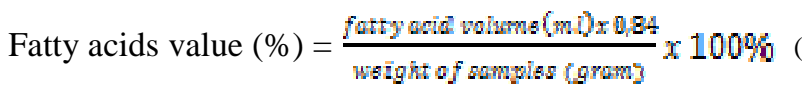
(4)

$0,84=$ certainty value of fatty acids at $100^{\circ} \mathrm{C}$

\section{Unsanpoaniable Matter [11]}

5 grams of sample was put into erlemenyer $250 \mathrm{ml}$, added $10 \mathrm{ml}$ of $0.5 \mathrm{~N} \mathrm{KOH}$ in alcohol and then heated over a water bath for approximately 1 hour. After the sample was cooled, added phenolphthalein indicator and titrated with $0.5 \mathrm{~N} \mathrm{HCl}$. For blank sample was using $70 \mathrm{ml}$ of neutral alcohol to replace the samples. The procedure was the same as the work samples.

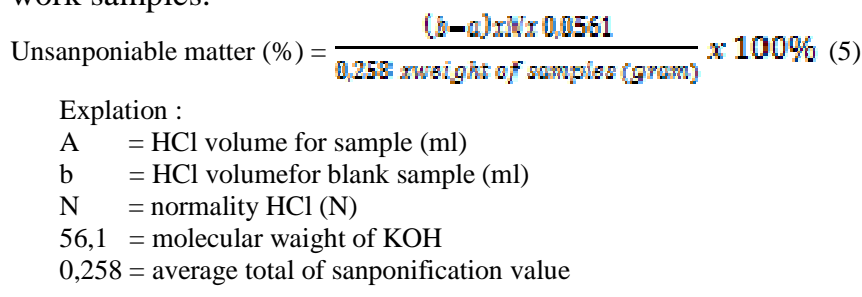

\section{N. Free Alkali [11]}

Boiled neutral alcohol by boiling $100 \mathrm{ml}$ of alcohol in 250 $\mathrm{ml}$ erlemenyer flask, added $0.5 \mathrm{ml}$ of phenolphthalein indicator and cooled until $70^{\circ} \mathrm{C}$. Then neutralize with $0.1 \mathrm{~N}$ $\mathrm{KOH}$ in alcohol.

\pm 5 gram of samples was inserted it into the neutral alcohol above, added boiling stones, pairs of upright coolers, and heated to quickly dissolve over a water bath, then simmered for 30 minutes. If wasn't alkaline formed (not colored red), cooled to $70^{\circ} \mathrm{C}$ and titrated with $0.1 \mathrm{~N} \mathrm{KOH}$ solution in alcohol to arise red color, hold for 15 seconds.

$$
\text { Alkali Free }=\frac{V_{x N x} 0,205}{W} \times 100 \%
$$

$$
\begin{array}{ll}
\mathrm{V} & =\mathrm{KOH} 0,1 \mathrm{~N} \text { used }(\mathrm{ml}) \\
\mathrm{N} & =\text { normality of } \mathrm{KOH} \\
\mathrm{W} & =\text { weight of samples }(\mathrm{gram}) \\
0,205 & =\text { weight of lauric acids }
\end{array}
$$

If the sample contains many insoluble parts of soap, for not to be interfered, strain before titration performed. If the above-mentioned alkaline solution (phenolphthalein indicator red colored), then examined not the free fatty acids but alkali-free with titrates using $0.1 \mathrm{~N} \mathrm{HCl}$ in alcohol from the micro biuret, right until the red color disappeared. 
Free alkali is counted as $\mathrm{NaOH}=\frac{V x N r 004}{\text { weight of somples }} \times 100 \%$ (7)

O. $p H[12]$

$\mathrm{pH}$ soap was measured by using $\mathrm{pH}$ meter. Calibrated $\mathrm{pH}$ meter using standard which was $\mathrm{pH} 7$ buffer solution. Electrodes were washed with distilled water, then dried with paper towels. Measurement of $\mathrm{pH}$ soap done by diluting 1 gram of soap with $10 \mathrm{ml}$ of distilled water in a cup, then the electrode was dipped into the solution and let it move up to the position of a constant number determined $\mathrm{pH}$ of soap.

\section{P. Insoluble parts in alcohol [11]}

5 grams of sample was put into a $200 \mathrm{ml}$ beaker, added 10 $\mathrm{ml}$ of ethyl alcohol $95 \%$ and steamed it until dry. The treatment was repeated three times. The sample was then dissolved in $100 \mathrm{ml}$ of neutral alcohol, then filtered using vacum suction through gooch rate which has been coated with a sintered glass filter paper which have known weight. During construction, the gooch rate should be covered with a watch glass. The residue retained by the filter paper rinsed with neutral alcohol. Filter paper was dried at a temperature of $105^{\circ} \mathrm{C}$ to constant weight and then weighed to determine final weight.

Insoluble parts in alcohol $(\%)=\frac{\text { weight of sompiss (grom) }}{\text { waight of resiolue (grom) }} 100 \%$

\section{Q. Irritation test [12]}

Took a \pm 0.1 grams of soap that has been soaked in water. Then applied to the skin, allowed for \pm 1 hour, observed the symptoms caused after applied. Irritation test assessment sheet of transparent soap with the addition of green tea extract can be seen in Appendix 4.

\section{R. Antioxidant Activity [13]}

$2 \mathrm{ml}$ of sample was mixed with $2 \mathrm{ml}$ of methanol solution containing $80 \mathrm{ppm}$ DPPH. The mixture was then stirred and allowed to stand for 30 minutes in a dark room. Measurements were performed by using a spectrophotometer with absorbance readings $\lambda 517 \mathrm{~nm}$. Blank sample used was methanol and the spectrophotometer used was Shimadzu spectrophotometer UV-1800 series.

DPPH scavenging activity $=\left(1-\frac{\text { aborben a of sampal }}{\text { aborkance of blenk sampla }}\right) \times 100 \%$

\section{S. Antimicrobial Test [14]}

Antimicrobial test method used method of Diffusion Plate Agar. This test was performed on the surface of a solid medium, namely, Nutrient Agar (NA). Microbe was grown on the surface of the medium. Then in a medium containing microbes was attached paper disc that has been soaked in a solution of soap and incubated for $1 \times 24$ hours. After that, the measured area / clear zone arised.

Determination of antimicrobial test procedures of transparent soap with the addition of tea extracts:

1) Sterilization Equipment: Petri dish, tweezers and spatula, micro pipette, beaker, distilled water were sterilized in an autoclave at a pressure of 1 atm, a temperature of $121^{\circ} \mathrm{C}$ for \pm 45 minutes. Ose needle sterilized with a bunsen flame, allowed to stand several times and repeated the sterilization for each use.

2) Preparation of bacteria suspension of Staphylococcus aureus : About $5 \mathrm{ml}$ physiological saline was inserted in a test tube. Then crushed pure cultures of bacteria Staphylococcus aureus in 1 ose, put into a test tube and homogenized with a vortex, after homogeneous pour saline that had contained the bacteria into the media NA, allowed to stand 10 minutes.

3) Test Antimicrobial Soap Transparent : Antimicrobial test that used paper discs made by dissolving 5 grams of transparent soap into $45 \mathrm{ml}$ of distilled water in a beaker. Paper discs soaked into it for an hour, then placed on the media discs that have been implanted NA bacteria. Then incubated in an incubator at $37^{\circ} \mathrm{C}$ for $1 \times 24$ hours. Diameter zones of inhibition were measured with calipers and ruler.

\section{RESULTS AND DISCUSSION}

\section{A. Sensory Evaluation Test Color, Aroma, and Transparency}

Sensory evaluation test can determine panelist preferences toward the effects of the addition of green tea extract transparent soap, through observation of color, aroma, hardness, foam stability, and transparency which were conducted by 20 panelists. Results of sensory evaluation test to transparent soap with the addition of green tea extract can be seen in Table 2 .

TABLE II

RESULTS OF SENSORY EVALUATION TEST TO TRANSPARENT SOAP WITH THE ADDITION OF GREEN TEA EXTRACT FOR COLOR, AROMA, AND TRANSPARENCY

\begin{tabular}{|l|l|l|l|}
\hline \multirow{2}{*}{ Treatments } & \multicolumn{3}{c|}{ like + very like (\%) } \\
\cline { 2 - 4 } & Color & Aroma & Transparency \\
\hline A (without green tea extract) & 50 & 50 & 90 \\
\hline B (green tea extract 0,5\%) & 80 & 45 & 95 \\
\hline C (green tea extract 1\%) & 50 & 45 & 60 \\
\hline D (green tea extract 1,5\%) & 45 & 50 & 30 \\
\hline E (green tea extract 2\%) & 25 & 50 & 20 \\
\hline
\end{tabular}

Results showed that transparent soap with the addition of green tea extract had range of panelist preferences on color between $25 \%$ - $80 \%$. Increasingly concentrated green tea extract added to soap resulting brownish to the transparent soap. Green tea extract was greenish brown. The green color of the tea leaves is determined by the presence of chlorophyll. In the process of enzyme inactivation by using heat, chlorophyll compounds was converted that cause a change of color of fresh green to olive green because chlorophyll converted into feofitin. In very acidic condition, feofitin will be converted into the feofirbid brownish green [15]. However, when added into a transparent soap, green is not too visible and most dominant color is brown.

The addition of green tea extract did not affect the aroma of transparent soap transparent soap. All of transparent soap almost had the same scent, that scent of coconut oil. Sensory evaluation results obtained transparency of the soap had range between $20-95 \%$. The addition of green tea extract in a transparent soap with a concentration of $2 \%$ caused the soap had dark brown color so that transparency was not able to seen again. 


\section{B. Hardness}

Based on the analysis of variance, the addition of green tea extracts in the transparent soap was not significantly affected to its hardness at significance level $(\alpha=5 \%)$. The average hardness score of transparent soaps can be seen in Table 3.

TABLE III

HARDNESS SCORE OF TRANPARENT SOAP WHICH ADDITION OF GREEN TEA EXTRACT

\begin{tabular}{|l|c|c|}
\hline \multicolumn{1}{|c|}{ Treatments } & $\begin{array}{c}\text { (Hardness) } \\
\left(\mathbf{N} / \mathbf{c m}^{2}\right)\end{array}$ & $\begin{array}{c}\text { (Hardness) } \\
\text { Sensory (\%) }\end{array}$ \\
\hline D (Green tea extract1,5\%) & 2,75 & 50 \\
\hline E (Green tea extract 2\%) & 2,90 & 35 \\
\hline B (Green tea extract0,5\%) & 3,14 & 40 \\
\hline C (Green tea extract1\%) & 3,23 & 65 \\
\hline A(Without green tea extract) & 3,96 & 35 \\
\hline Coef div =13,94\% & \\
\hline
\end{tabular}

Resuts showed that hardness score of trasparant soap using texture analyzer had ranges from 2.75 to $3.9 \mathrm{~N} / \mathrm{cm} 2$. The $\mathrm{C}$ chain of fatty acids used affected to the softness / hardness of soap. $\mathrm{C}$ chain of fatty acids which produces suitable hardness in soap are $\mathrm{C}_{16}-\mathrm{C}_{18}$ [16]. Green tea contains linolenic fatty acids $\left(\mathrm{C}_{18}\right)$ and linoleic $\left(\mathrm{C}_{18}\right)$ in small amounts. This caused the addition of green tea extracts in transparent soap did not affect to the harndess.

\section{Foam Stability}

Based on the analysis of variance, the addition of green tea extracts in the transparent soap was not significantly affected to foam stability at significance level $(\alpha=5 \%)$. The average of foam stability percentages can be seen in Table 4 .

TABLE IV

The Average of Foam Stability Percentages on Tranparent SoAP

\begin{tabular}{|l|c|c|}
\hline \multicolumn{1}{|c|}{ Treatments } & $\begin{array}{c}\text { Foam } \\
\text { Stability } \\
(\boldsymbol{\%})\end{array}$ & $\begin{array}{c}\text { Foam Stability } \\
\text { using Organoleptic } \\
\text { Test(\%) }\end{array}$ \\
\hline A (Without Green Tea Extract) & 46,26 & 25 \\
\hline C (Green tea extract 1\%) & 46,84 & 65 \\
\hline E (Green tea extract 2\%) & 48,95 & 70 \\
\hline D (Green tea extract 1,5\%) & 50,10 & 70 \\
\hline B (Green tea extract 0,5\%) & 50,63 & 65 \\
\hline Coef div =5,50\% & \multicolumn{2}{|l}{} \\
\hline
\end{tabular}

Results showed that the average of foam stability on transparent soap had ranges between 46.26 to $50.63 \%$. Characteristics of the foam was influenced by the presence of the active ingredient of soap such as surfactant, foam stabilizer, and fatty acids composition that is used. Lauric acid and myristic can produce soft foam, while palmitic and stearic acids have a foam which can stabilize properties. Oleic acid and ricinoleic can generate stable foam and soft [17].

\section{Chemical Properties Water Content}

This analysis was conducted to determine the amount of water content. The amount of water added to the soap will affect to the solubility of soap in the water when it used. Based on the analysis of variance, the addition of green tea extracts to the transparent soap was not significantly affected to its water content at significance level $(\alpha=5 \%)$. The average of water content on transparent soap can be seen in Table 5.

TABLE V

The AVERAgE OF WATER CONTENT ON TRANSPARENT SOAP WHICH GreEN TEA EXTRACT ADDED

\begin{tabular}{|l|c|}
\hline \multicolumn{1}{|c|}{ Treatments } & Water Content (\%) \\
\hline D (Green Tea Extract1,5\%) & 34,52 \\
\hline E (Green Tea Extract2\%) & 35,35 \\
\hline B (Green Tea Extract 0,5\%) & 35,52 \\
\hline C(Green Tea Extract1\%) & 36,65 \\
\hline A(Without Green Tea Exract) & 39,10 \\
\hline Coef div $=5,39 \%$ & \\
\hline
\end{tabular}

Results showed that the average of water content had range from 34.52 to $39.10 \%$. The water content of transparent soaps were above the maximum limit according to SNI 06-3532-1994 which is $15 \%$. Glycerin is a humectant which is hygroscopic which can absorb moisture from humid air up to a certain amount [18].

\section{E. Fatty Acids Value}

The amount of fatty acids is a overall fatty acid which are bound between sodium or free fatty acids and neutral fatty acids (triglycerides or fats saponified). Fatty acids are the main components of fat or oil. Characteristics of a soap is strongly influenced by the characteristics of the oil used. Each oil has a dominant types of fatty acids. Fatty acids will determine the characteristics of soap.

Based on the analysis of variance, the addition of green tea extracts to the transparent soap was not significantly affected to fatty acids valueat significance level $(\alpha=5 \%)$. The average amount of fatty acidson transparent soap can be seen in Table 6.

TABLE VI

The Average AMOUnT OF FATTY ACIDS ON TransParent SOAP WITH GREEN TEA EXTRACT

\begin{tabular}{|l|c|}
\hline \multicolumn{1}{|c|}{ Treatments } & Fatty Acids Value (\%) \\
\hline A (Without Green Tea Extract) & 24,56 \\
\hline B (Green Tea Extract0,5\%) & 25,02 \\
\hline C (Green Tea Extract1\%) & 28,33 \\
\hline D (Green Tea Extract1,5\%) & 28,91 \\
\hline E (Green Tea Extract2\%) & 29,78 \\
\hline Coef div $=1,51 \%$ & \\
\hline
\end{tabular}

Results showed that the average amount of fatty acids on transparent soap had ranges from 24.56 to $29.78 \%$. The amount of fatty acids increased by the addition of green tea extract, because green tea contains fat formed linoleic acid and linolenic acid (19). The amount of fatty acids obtained from the analysis conducted still not meet the minimum criteria set by SNI 06-35-32-1994 that is at least 70\%.

\section{F. Unsanponiable Matter}

Based on the analysis of variance, the addition of green tea extracts to the transparent soap was not significantly affected to unsanponiable matter on transparent soapat significance level $(\alpha=5 \%)$. The average percentages of unsanponiable matter of transparent soap can be seen in Table 7. 
TABLE VII

The Average Percentages of UnsanPoniable Matter on TRANSPARENT SOAP ADDED GREEN TEA EXTRACT

\begin{tabular}{|l|c|}
\hline \multicolumn{1}{|c|}{ Treatments } & Unsanponiable Matter (\%) \\
\hline A (Green Tea Extract) & 10,13 \\
\hline B (Green Tea Extract0,5\%) & 10,42 \\
\hline C (Green Tea Extract1\%) & 11,72 \\
\hline D (Green Tea Extract1,5\%) & 11,87 \\
\hline E (Green Tea Extract2\%) & 12,87 \\
\hline Coef div $=0,81 \%$ & \\
\hline
\end{tabular}

According to ISO (1994), maximum level of unsanponiable matter is $2.5 \%$. Based on the results of analysis showed that the content of unsanponiable matter on transparent soap had ranges from 10.13 to $12.87 \%$. It did not meet the quality criteria of unsanponiable matter according to SNI.

Unsanponiable matter increased with the addition of green tea extract, because green tea contains sterols in the form of stigmasterol and dyestuffs. The compounds are oil soluble and not saponifiable by alkali soda such as sterols, dye and hydrocarbons. Unsanponiable matter showed a fatty acid in free form which does not react with alkali to form soap [20].

\section{G. Free Fatty Acid/ Alkali Free}

From the research that has been done, each treatment has a negative of alkali free, it means transparent soap produced no excess alkaline, but have excess fatty acids. Based on the analysis of variance, the addition of green tea extracts to the transparent soap was not significantly affected to free fatty acids / akali free on transparent soap at significance level $(\alpha$ $=5 \%$ ). The average free fatty acids on transparent soap can be seen in Table 8 .

TABLE VIII

The Average Free FATty ACIDSON TRANSPARENT SOAPADDED GREEN TEA EXTRACT

\begin{tabular}{|l|c|}
\hline \multicolumn{1}{|c|}{ Treatments } & Free Fatty Acids (\%) \\
\hline D (Green Tea Extract1,5\%) & 0,23 \\
\hline E (Green Tea Extract2\%) & 0,23 \\
\hline C (Green Tea Extract1\%) & 0,25 \\
\hline B (Green Tea Extract0,5\%) & 0,25 \\
\hline A (Without Green Tea Extract) & 0,25 \\
\hline Coef div = 16,60\% \\
\hline
\end{tabular}

Results showed that the average of free fatty acids on transparent soap had ranges from 0.23 to $0.25 \%$. Free fatty acidson this transparent soap has fulfilled SNI 06-3532-1994, which is maximum contained $2.5 \%$.

\section{H. $p H$}

$\mathrm{pH}$ is a chemical parameter for knowing characteristic of the soap kind of alkaline or acidic [9]. Based on the analysis of variance, the addition of green tea extracts to the transparent soap was not significantly affected to $\mathrm{pH}$ of transparent soapat significance level $(\alpha=5 \%)$. The average $\mathrm{pH}$ of transparent soap can be seen in Table 9.

Results showed that the average $\mathrm{pH}$ of transparent soap had ranges from 9.78 to 10.21 . The $\mathrm{pH}$ value of the transparent soapswere in compliance with SNI 06-35321994, which ranged from 8-11, so it can be said that the transparent soaps were applicable. Soap that has a $\mathrm{pH}$ that is too high or too low will cause irritation to the skin.
TABLE IX

The Average PH of Transparent SoAP With GreEn TEA EXTRACT

\begin{tabular}{|l|c|}
\hline \multicolumn{1}{|c|}{ Treatments } & pH \\
\hline E (Green Tea Extract 2\%) & 9,78 \\
\hline D (Green Tea Extract 1,5\%) & 10,01 \\
\hline C (Green Tea Extract 1\%) & 10,09 \\
\hline B (Green Tea Extract 0,5\%) & 10,19 \\
\hline A (Without Green Tea Extract) & 10,21 \\
\hline Coef div =1,66\% \\
\hline
\end{tabular}

\section{Insoluble Parts in Alcohol}

Transparent soap used alcohol as a solvent and a transparent agent. A substance can be dissolved in a solvent if it has the same polarity value [21]. Based on the analysis of variance, the addition of green tea extracts to the transparent soap was significantly affected to insoluble parts in alcohol on transparent soap at significance level $(\alpha=5 \%)$. Percentages of insoluble parts in alcohol can be seen in Table 10.

TABLE X

Processing Percentages of Insoluble Parts in AlCOHOL ON TRANSPARENT SOAP ADDED GREEN TEA EXTRACT

\begin{tabular}{|l|l|}
\hline \multicolumn{1}{|c|}{ Treatments } & \multicolumn{1}{c|}{ Insoluble Part in Alcohol (\%) } \\
\hline A (Green Tea Extract) & $1,25^{\mathrm{a}}$ \\
\hline B (Green Tea Extract 0,5\%) & $1,42^{\mathrm{ab}}$ \\
\hline C (Green Tea Extract 1\%) & $1,70^{\mathrm{bc}}$ \\
\hline D (Green Tea Extract 1,5\%) & $1,81^{\mathrm{c}}$ \\
\hline E (Green Tea Extract 2\%) & $2,08^{\mathrm{c}}$ \\
\hline Coef div $=15,18 \%$ & \\
\hline
\end{tabular}

Note: the numbers which are followed by different superscript showing significantly different according to DNMRT at 5\% significance level.

Based on variance analysis results were indicated that the addition of green tea extract on transparent soap significantly different at 5\% level by using DNMRT at insoluble part in alcohol. Higher concentration of green tea extract were added in transparent soap, alcohol-insoluble portion more higher on the transparent soap. Oil and grease slightly soluble in alcohol, but will dissolve completely in ethyl ether and carbon disulfide. The material is not soluble in alcohol is protein [20]. ASTM (2001) mentions the most part insoluble in alcohol is alkaline salts, such as carbonates, borates, silicates, phosphorus and sulfate, while other material is starch.

Green tea contains amino acids, carbohydrates, and catechins which form aromatic compounds. In addition, green tea extract contains sodium bicarbonate (NaHCO3) which serves to retain the dye chlorophyll in green tea. 0635-32-1994 ISO quality requirements stipulate that part insoluble in alcohol soap has maximum limit is $2.5 \%$. Based on the analysis showed that part insoluble in alcohol in a transparent soap added the addition of green tea extract on all treatments had qualified accordint to SNI 06-35-32-1994.

\section{J. Irritation test}

Irritation test results can be seen at Table 11. Results showed that transparent soaps added with green tea extract were applicable and safety which no irritation detected on skin. Skin irritation caused by the $\mathrm{pH}$ is too high or too low, high amount of ethanol added while processing producing high number of free alkali. In this research, $\mathrm{pH}$ and free 
alkali in the soap have met quality standards according to SNI 06-3532-1994.

TABLE XI

IRRITATION TEST RESULTS OF TRANSPARENTS SOAP WITH GREEN TEA EXTRACT

\begin{tabular}{|l|c|}
\hline \multicolumn{1}{|c|}{ Treatments } & Irritation Results \\
\hline A(Without Green Tea Extract) & 0 \\
\hline B (Green Tea Extract0,5\%) & 0 \\
\hline C (Green Tea Extract1\%) & 0 \\
\hline D (Green Tea Extract1,5\%) & 0 \\
\hline E (Green Tea Extract2\%) & 0 \\
\hline Coef div =0\% \\
Note: $0=$ no Irritated
\end{tabular}

\section{K. Antioxidant Activity}

Based on the analysis of variance, the addition of green tea extracts on transparent soap, was significantly affected to antioxidant acitivity at significance level $(\alpha=5 \%)$. The average of antioxidant activity on transparent soap can be seen in Table 12.

TABLE XII

The AVErage of ANTIOXIDANT ACTIVITy ON TRANSPARENT SOAP AdDED GREEN TEA EXTRACT

\begin{tabular}{|l|l|}
\hline \multicolumn{1}{|c|}{ Treatments } & \multicolumn{1}{c|}{ Antioxidant Activity } \\
\hline A(Without Green Tea Extract) & $0,83^{\mathrm{a}}$ \\
\hline B (Green Tea Extract 0,5\%) & $4,84^{\mathrm{b}}$ \\
\hline C (Green Tea Extract 1\%) & $9,46^{\mathrm{c}}$ \\
\hline D (Green Tea Extract 1,5\%) & $12,97^{\mathrm{d}}$ \\
\hline E (Green Tea Extract 2\%) & $15,21^{\mathrm{d}}$ \\
\hline Coef div = 15,76\% \\
\hline
\end{tabular}

Note:the numbers which are followed by different superscriptshowing significantly different according to DNMRT at 5\% significance level.

Antioxidant properties of green tea caused by catechins compound. Antioxidants can be used for food preservation, protecting the fat or oil food from oxidation, and protect oxidation on the sensitive vitamins [15]. Polyphenols as antioxidants work through four mechanisms, such as damaging free radicals, preventing the formation of free radicals through hydrogen bonding, deactivate singlet oxygen which acts as a free radical in the body, and to be bonded with metals [22]. Beside that, flavonols also have a role as an antioxidant in tea. Flavanols in green tea consists of quersetin, kaempferol, and mirisetin [15].

\section{Antimicrobial Test}

This analysis was conducted to determine the inhibitory diameter of transparent soap with the addition of green tea extract on the growth of Staphylococcus aureus bacteria. Results of analysis of variance, the addition of green tea extract to transparent soap significantly affected tothe inhibitory diameter of Staphylococcus aureus which also can be seen in Table 13.

Results showed that higher concentration of green tea extract were added to the transparent soap affected to get bigger of the inhibitory diameter of Staphylococcus aureus. This is because the content of catechins in green tea. Catechins destroy lipid bilayer membrane so that the cell loses its structure and function which ultimately lysis.
TABLE XIII

INHIBITORY DIAMETER OF STAPHYLOCOCCUS AUREUS BACTERIA ON TRASNPARENT SOAP WITH GREEN TEA EXTRACT

\begin{tabular}{|l|l|}
\hline \multicolumn{1}{|c|}{ Treatment } & \multicolumn{1}{c|}{ Inhibition area (mm) } \\
\hline A(Without Green Tea Extract) & $29,33^{\mathrm{a}}$ \\
\hline B (Green Tea Extract $0,5 \%)$ & $33,33^{\mathrm{b}}$ \\
\hline C (Green Tea Extract 1\%) & $35,00^{\mathrm{bc}}$ \\
\hline D (Green Tea Extract 1,5\%) & $36,67^{\mathrm{c}}$ \\
\hline E (Green Tea Extract2\%) & $42,00^{\mathrm{d}}$ \\
\hline Coef div $=4,91 \%$ & \\
\hline
\end{tabular}

Note: the numbers which are followed by different superscript showing significantly different according to DNMRT at 5\% significance level.

Epigallocatechin, epigallocatechin gallate and flavonols had a major role for bacterial fatty acids synthesis. Fatty acids in the bacteria used primarily to form cell membranes of bacteria [23]. The existence of barriers to the formation of fatty acids synthesis occur formation of cell membranes will be disturbed. This resulted in the structure and function of the bacterial cell membrane is damaged and eventually bacterial cell lysis and death (24). Catechins are highly soluble in the water and lipophilic cause catechins very easily attached to the protein also toxin in bacteria, thus forming a bond that inhibits adhesion in human cells [23].

\section{CONCLUSIONS}

Based the research it can be concluded that the addition of green tea extract on the transparent soap significantly affected to the insoluble part in alcohol, antioxidant activity, antimicrobial, and did not significantly affected to the moisture content, fatty acids velue, unsanponiable matter, free fatty acids, $\mathrm{pH}$, hardness, and foam stability. The best products based on the antioxidant activity was treatment $\mathrm{E}$ (Addition of green tea extract 2\%). Treatment E (Addition of green tea extract $2 \%$ ) had hardness $2,90 \mathrm{~N} / \mathrm{cm} 2$; foam stability $48.95 \%$; water content $35.35 \%$; fatty acids value $29.78 \%$; unsanponiable matter $12.87 \%$; free fatty acids $0,23 \%$; pH 9.78; Insoluble parts in alcohol $2.08 \%$; irritation value 0 ; antioxidant activity $15.21 \%$; and inhibitory diameter of antimicrobial $42 \mathrm{~mm}$. According to the sensory evaluation tests, percentages of panelist preferences on treatment $\mathrm{E}$ (addition of green tea extract $2 \%$ ) were $25 \%$ on color, $50 \%$ on aroma, $20 \%$ on transparency , $35 \%$ on hardness, and $70 \%$ on foam stability.

\section{REFERENCES}

[1] Hambali, E. 2005. Gaya Membuat Sabun Transparan untuk Gift dan Kecantikan. Jakarta: Penebar Swadaya.

[2] Shrivastava, S.B. 1982. Soap, Detergent and Parfume Industry. Small Industry Research Institute: New Delhi.

[3] Miller, A. L. 2005. Antioxidant Flavonoid: Stucture, Function and Clinical Usage.

[4] Picard, D. 1996. Teh Biochemistry of Green Tea Polyphenols and Tehir Potential Application in Human Skin Cancer. Alternat Med Rev1: 31-42.

[5] Adhami VM, Malik A, Zaman N, Sarfarz S, Siddiqui IA, Syed DN, Afaq F, Pasha FS, Saleem M \& Mukhtar H.2007. Combined inhibitory effects of green tea polyphenols and selective cyclooxygenase- 2 inhibitors on the growth of human prostate cancer cells both in vitro and in vivo. Clinical Cancer Research, 13, 16111619.

[6] Handoko, D. 2007.Pengaruh Tekanan dan Suhu pada Kondisi Evaporasi Ekstrak Daun Teh Hijau. [Skripsi]. Bogor: Institut Pertanian Bogor. 
[7] Yuswita, E. 2011. Pembuatan Sabun Transparan dari Minyak Kelapa dengan Aroma Jeruk Purut (Citrus hystrix). [Skripsi]. Padang: Universitas Andalas.

[8] Rahayu, W P. 1994. Penilaian Organoleptik Penuntun Pratikum. Bogor. Jurusan Teknologi Pangan dan Gizi Fakultas Teknologi Pertanian Institut Pertanian.180 hal.

[9] Widiyanti, Y. 2009. Kajian Pengaruh Jenis Minyak terhadap Mutu Sabun Transparan. [Skripsi]. Bogor. Fakultas Teknologi Pertanian. 67 hal.

[10] Awang, R., Whye, C.K., Basri, M., Ismail, R., Ghazali, R., and Ahmad, S., 2006, Alkanolamides from 9, 18-Dihydroxy Stearic Acid , J. Oil. Palm Res., 232, 235.

[11] SNI 06-3532.1994. Standar Mutu Sabun Mandi. Jakarta: Dewan Standarisasi Nasional.

[12] Hadia, P. R. 2006. Komposisi dan Evaluasi Hasil Pembuatan Sabun Padat Vigin Coconut Oil (VCO) dengan Sari Jeruk Nipis (Citrus Aurantifolia S). [Skripsi]. Padang. Jurusan Kimia Universitas Andalas.

[13] Huang, Yu-Ching.,Chang, Yung-Ho., dan Shao, Yi-Yuan. 2005. Effects of Genotype and Treatment on teh Antioxidant Activity of Sweet Potato in Taiwan. Food Chemistry.

[14] Zulkilfli. 2013. Pengaruh Penambahan $\mathrm{NaOH}$ dalam Pembuatan Sabun Transparan dari PFAD (Palm Fatty Acid Distilate) dengan Penambahan Minyak Nilam (Patchouli Oil). [Skripsi]. Padang: Universitas Andalas.

[15] Alamsyah, N.A. 2006. Taklukkan Penyakit dengan Teh Hijau. Jakarta: Penerbit Agrimedia Pustaka.
[16] Purnamawati, D. 2006.Kajian Pengaruh Konsentrasi Sukrosa dan Asam Sitrat terhadap Mutu Sabun Transparan. [Skripsi]. Bogor: Institut Pertanian Bogor.

[17] Cavitch, S.M. 2001. Choosing Your Oils, Properties of Fatty Acids. [online] http :// user.silverlink.net.html diakses tanggal 18 Oktober 2013.

[18] Handayani, H.C. 2009.Pengaruh Peningkatan Konsentrasi Ekstrak Etanol 96\% Biji Alpukat (Perseae Americana Mill) terhadap Formulasi Sabun Padat Transparan. [Skripsi]. Jakarta: Uin Syarif Hidayatullah.

[19] Cabrera, C., Artacho, R and Gime, R.2006.Beneficial Effects of Green T. Journal of Tea American College of Nutrition. 25(2): 79-99.

[20] Ketaren, S. 1986. Pengantar Teknologi Minyak dan Lemak Pangan. UI-Press: Jakarta.

[21] Fachmi, C. 2008. Pengaruh Penambahan Gliserin dan Sukrosa Terhadap Mutu Sabun Transparan.[Skripsi]. Bogor: Institut Pertanian Bogor.

[22] Rohdiana, D. 2011. Teh Mencegah Kanker Payudara. [online] http://blesstealampung.blogspot.com diakses pada tanggal 18 Oktober 2013.

[23] Zhang, Y. M dan Rock, C. O. 2004. Evaluation of Epigallocatechin Gallate and Related Polyphenols as Inhibitors of teh FabG and Fabl Reductases of Bacterial Type II Fatty Acid Syntehtase. Teh American Society for Biochemical and Molekular Biology. Memphis: JBC Papers in Press.

[24] Rizky, O. 2006. Uji Aktivitas Antibakteri Ekstrak Teh Hijau (Camellia sinensis) terhadap Stahylococcus aureus ATCC 6538 dan Escherichia coli ATCC 11229 Secara In Vitro [Skripsi]. Jakarta: Fakultas Kedokteran Universitas Muhammadiyah Surakarta. 